\title{
漁業用餌料およびコンクリート魚礁での 焼酎かすの有効活用
}

焼酎を製造する際に生じる焼酎かすは，これまで海洋投入処分されてきたが, 地球環境への配慮から，新 たな有効活用法や処分法の開発が行われている。メタン発酵によるメタンガスの回収や家畜飼料への利用な どがその一例であるが, 筆者は, 焼酎かすの特徵的な匂い刺激や豊富なアミノ酸といった特性を見直し, 水 質環境に優しい有効利用法の開発について取り組まれてきた。今回は漁業用飼料やコンクリートの材料とし て水の代わりに焼酎かすを用いた人工魚礁「焼酎かすコンクリート」の研究開発の一端を解説していただい た。

\section{江 幡 恵 吾}

\section{1. 水産業における「焼酎かす」の有効活用}

水中に生息する魚類は, 視覚, 聴覚, 嗅覚, 味覚な どの感覚の中でも, 特に嗅覚の機能が優れていると言 われている ${ }^{1,2)}$ 。アミノ酸はわたしたち人間をはじめ, すべての生物にとってなくてはならない重要なもので ある。アミノ酸は人間にとって無臭の物質であるが魚 類にとっては極めて有効な匂い刺激となる ${ }^{3)}$ 。これま での研究例によると, アミノ酸は魚類の摂餌行動など に打いて重要な化学刺激になること ${ }^{4)}$ や，ノリの生長, 特に幼芽期の生長促進に関係のあることが報告されて いる ${ }^{5,6)}$ 。

焼酎の製造過程で排出される燒酎かすは（写真 1$)$, ほとんどが水分であるが，残りの固形分の中には夕ン パク質，アミノ酸，ビタミン $\mathrm{E}$ な゙の有機成分が含 まれている7)。わたしの研究室で焼酎かすの有効活用 に関する研究を始めたのは平成 16 年であり，当時は 全国的な焼酎ブームが沸き起こり，焼酎生産量が右肩 上がりに増え続ける一方で，焼酎かすの処理が社会問 題化していた ${ }^{8)}$ 。焼酎かすの成分を分析したところ, グルタミン酸, アラニン，グリシンなど少なくとも 17 種類のアミノ酸が含まれていることが分かり，こ れらのアミノ酸成分に着目して，魚類を漁獲するため に使用される慨料や海中に設置される人工魚礁に有効

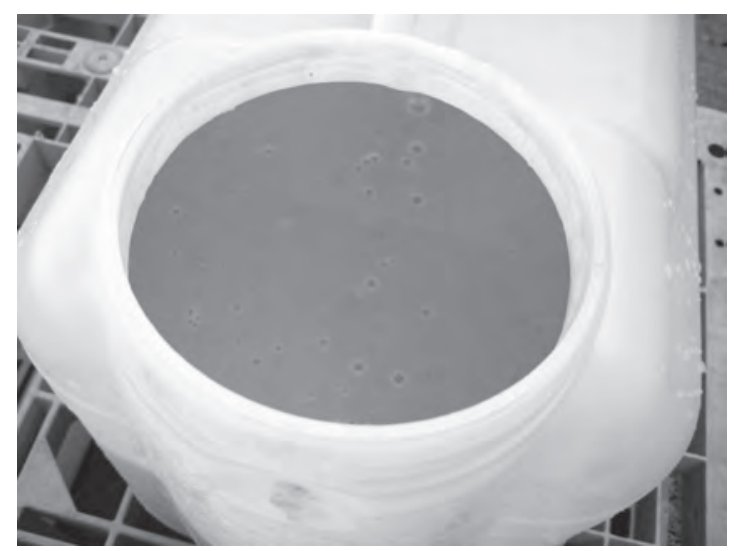

写真 1 いも焼酎かす

活用する研究開発に取り組んできた。

\section{2. 焼酎かすに対するトコブシの摂餌特性について}

トコブシはアワビと同じミミガイ科の貝であり, 鹿 児島県では種子島が代表的な産地である。本研究では， トコブシのいも焼酎かす，麦焼酎かすに対する摂餌特 性を明らかにする実験を行った ${ }^{9)}$ 。いも焼酎かす，麦 焼酎かすはいずれも液状であるため，これを固化する ために寒天粉末を使用した。実験では比較のために, いも焼酎かす，麦焼酎かすを固化したものに加えて， トコブシが好む海藻（乾燥ワカメ）を固化したもの,

Effective Utilization of Waste Stillage from Shochu Distillery for Fishing Bait and Artificial Reef Keigo EBata (Faculty of Fisheries, Kagoshima University) 
コントロールとして海水のみを固化したものの合計 4 種類を使用した。実験には種苗放流用に飼育された卜 コブシの稚貝（平均殼長 $26.0 \mathrm{~mm}$, 平均体重 $2.1 \mathrm{~g}$ ) を使用した。はじめに実験水槽（縦 $40 \mathrm{~cm}$, 横 $26 \mathrm{~cm}$, 高さ $28 \mathrm{~cm}$, 水深 $22 \mathrm{~cm}$ ）を 4 つ用意して, その中に トコブシを 40 個体ずつ入れて, 水槽の環境に馴致さ せるために, 約 1 ケ月間市販の乾燥ワカメを与えながら 飼育した。トコブシは夜間に行動が活発になるため ${ }^{10,11)}$, 実験時間は夕方 18 時から翌朝 8 時までとした。実験 開始時に餌料の大きさを縦 $4.0 \mathrm{~cm}$, 横 $2.0 \mathrm{~cm}$, 高さ $2.5 \mathrm{~cm}$, 重量 $27.0 \mathrm{~g}$ に統一して水槽内に入れて, 実験 終了時に餌料の減少量を求めた（写真 2 )。実験の結果, 海藻餌料, いも焼酎かす餌料, 麦焼酎かす餌料, コン トロール飭料のすべてにおいてトコブシによる摂飭が 確認され, 餌料の減少量は海藻餌料 $(9.82 \mathrm{~g})$, いも 焼酎かす餌料 $(5.44 \mathrm{~g})$, 麦焼酎かす餌料 $(2.96 \mathrm{~g})$, コントロール餌料（2.21 g）の順に多くなり，海藻餌 料といも焼酎かす餌料がコントロール慨料に比べて有 意に高くなったが $(\mathrm{P}<0.05)$ ，麦焼酎かす餌料とコ ントロール餌料の間には有意な差は見られなかった。

いも焼酎は，さつまいもが収穫された後に一斉に製 造が始まるために，いも焼酎かすは秋から冬にかけて 集中して多量に発生している。養魚用飼料に㧍ける代 替タンパク質源として焼酎かすの利用がカンパチ， マ ダイ, トラフグ, ヒラメなどで検討され，一部ではす でに実用化されている ${ }^{8)}$ 。本実験の結果，トコブシが いも焼酎かす慨料を摂餌することが確認されたことか

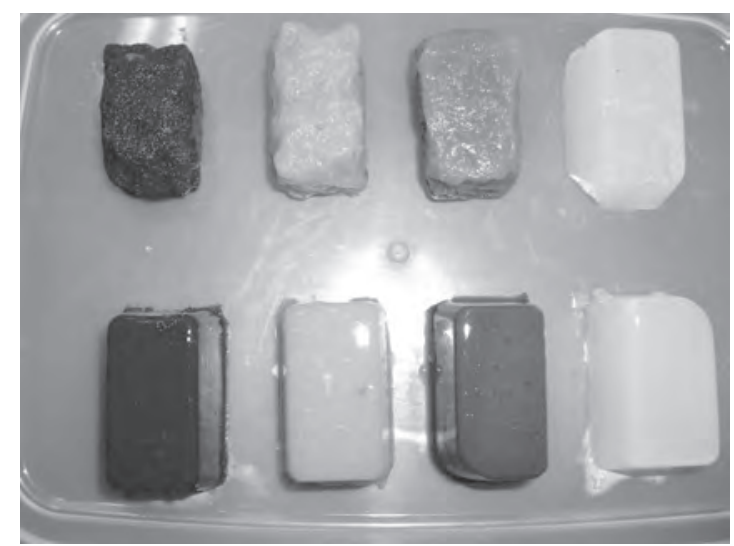

写真 2 寒天粉末で固化した餌料 (左から海藻, いも 焼酎かす，麦焼酎かす，海水，上側は実験終 了後，下側は実験前の状態を示す）
ら，今後トコブシの養殖を検討するにあたって，トコ ブシの餌料となる海藻類が減少する冬季の期間に, 多 量に発生するいも焼酎かすを慨料の一部として利用で きる可能性があると考えている。

\section{3. マダコを漁獲するためのいも焼酎かす餉料に ついて}

かご漁具は日本国内をはじめ, 世界各地で幅広く使 用されており, 対象魚を生きた状態で漁獲するため, 鮮度の良い状態で出荷ができるメリットを持っている。 また, サイズの小さな個体が漁獲されても, 再び海中 に放流ができるため, 環境にもやさしい漁法であると いえる。鹿児島の沿岸では初夏から秋にかけて, かご 漁具を用いたマダコ漁業が行われている。かごの中に はマダコを誘引するためにサバ類やイワシ類などが餌 として入れられるが, これらは人間の食料となりえる ものであり，食料を使って食料を生産することはあま り効率の良いことではない。また, 近年の世界におけ る水産物の需要の高まりを受けて, これまで漁業用餌 料として使用していた冷凍魚が食料として流通しはじ め, 価格の高騰が起きている。このような背景から, 食品廃棄物などを利用した代替餌料の開発が望まれて いる。焼酎かすには魚類などの水生生物に対して誘引 効果を持つアミノ酸などの物質が含まれるため, 漁業 用餌料として有効活用できる可能性がある。そこで本 実験では，水槽実験および現場海域における実証試験 を行い, いも焼酎かす餌料の漁業用餌料としての可能 性を検証した ${ }^{12)}$ 。

\section{（1）水槽実験による焼酎かすに対するマダコの誘引 効果試験}

実験は鹿児島大学水産学部東町ステーションにある 屋内水槽（縦 $7.5 \mathrm{~m}$, 横 $4.5 \mathrm{~m}$, 水深 $0.5 \mathrm{~m}$ ）で行った。 いも焼酎かすを寒天粉末で固化した飭料, 従来餌料と して使用されているマサバの切り身を入れたかご（縦 $220 \mathrm{~mm}$, 横 $455 \mathrm{~mm}$, 奥行 $600 \mathrm{~mm}$, 入口が側面に 2 つ）をそれぞれ 1 個ずつ, コントロールとして慨料を 入れないかごの合計 3 つのかごを水槽中央部に設置し た後に, 生きたマダコを水槽の中に入れて, デジタル ビデオカメラを用いてマダコの行動を撮影した。その 結果, いも焼酎かす飭料とマサバのどちらの慨料にお いてでも，マダコはかごに接近し，かごに接触するな どの行動を経て, 最終的にはかごの中に入る行動が観 


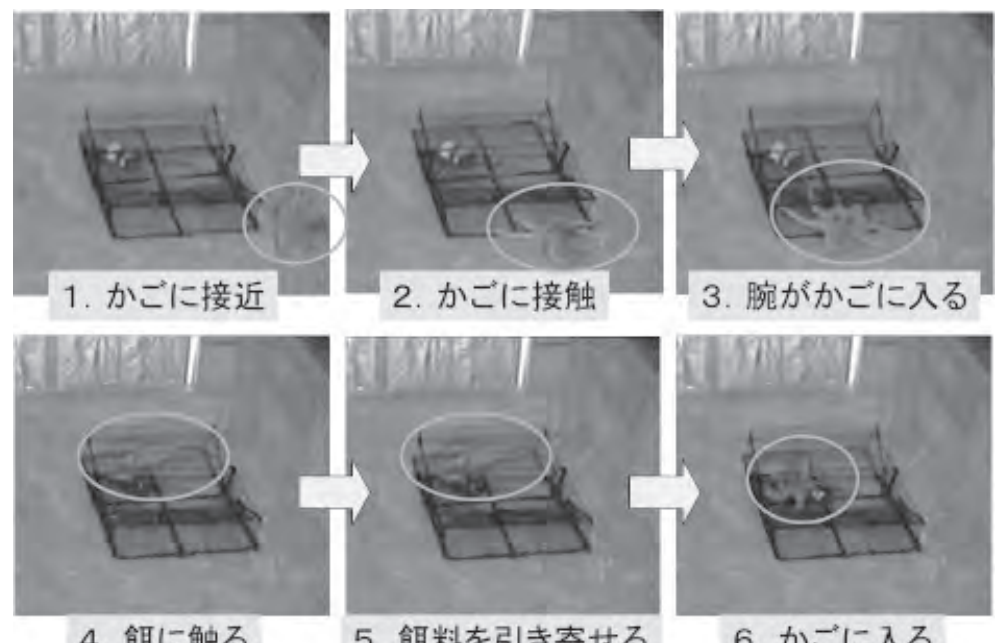
4. 餌に触る
5. 餌料を引き寄せる
6. かごに入る

第1図 マダコのかごに対する行動

察された（第 1 図）。餌料を入れなかったコントロー ルのかごでは，マダコはかごに接近はしたが，それ以 外の行動は観察されなかった。

\section{（2）現場海域でのいも焼酎かす餌料の漁獲試験}

試験操業は, 鹿児島大学水産学部東町ステーション 地先の沿岸で合計 11 回行った。いも焼酎かす慨料, マサバの切り身を入れたかごをそれぞれ 10 個，コン トロールとして餌を入れないかごを 10 個として，合 計 30 個のかごを海底に設置した。その後, 朝 9 時と 夕方 16 時にかごを水中から取り上げて，すべての漁 獲物を取り出した後に, 新しい慨料と交換して再度, 海底に設置することを繰り返し（写真 3), 餌料の重 量を操業の前後で測定して重量の変化を求めた。試験

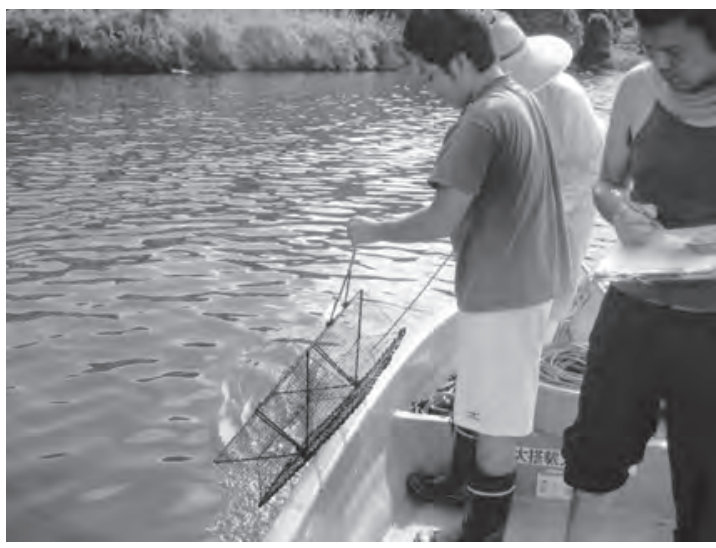

写真 3 いも焼酎かす餌料を用いたかごの試験操業
操業の結果，いも焼酎かす餌料ではマダコ, カワハギ, メバルの 3 種類の有用魚種が漁獲され (写真 4), マ サバではマダコ, ウナギ, カサゴ, カワハギ, シロギ ス, クサフグ, イシガニの 7 種類の有用魚種が漁獲さ れた。マダコの漁獲尾数を比較すると、、サバでは合 計 14 尾，いも焼酎かす餌料では合計 6 尾であったが, 各操業におけるマダコの漁獲については，いも焼酎か す餌料とマサバとの間では有意な差が見られなかった。 操業前後における餌料の減少量は，マサバでは平均 で $75.4 \mathrm{~g}$ であったが，いも焼酎かす餌料では製作時 に使用した寒天粉末の量を $20 〜 50 \mathrm{~g}$ としたために, その量によって餌料の固化強度が異なり, 餪料の減少 量は寒天粉末の配合量が $20 \mathrm{~g}$ のきは $130.1 \mathrm{~g}, 50 \mathrm{~g}$

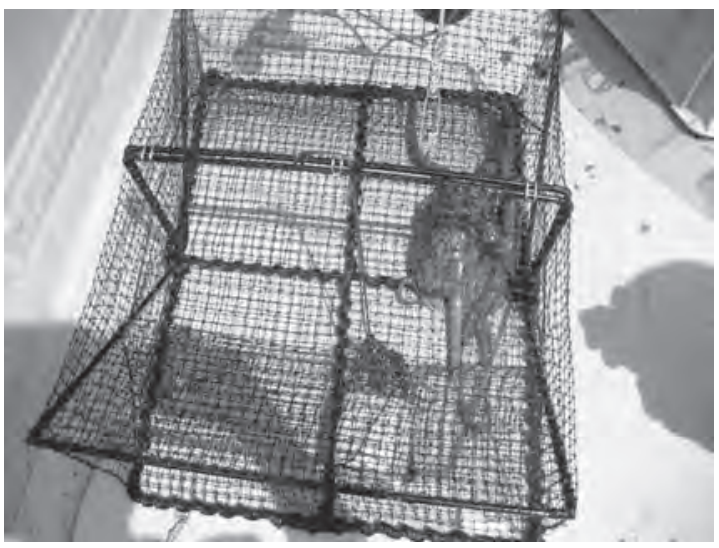

写真 4 いも燒酎かす餌料で漁獲されたマダコ

第 111 巻 第 3 号 
のときは $13.3 \mathrm{~g}$ であった。マダコの漁獲尾数は, 寒 天粉末が $50 \mathrm{~g}$ のときは合計 3 尾, $20 \mathrm{~g}$ のときは合計 2 尾となり, 寒天粉末量が $20 \sim 50 \mathrm{~g}$ の範囲ではマダ コの漁獲に与える影響はみられなかった。

本実験の結果，いも焼酎かす餌料で魚種数が減少す る傾向が見られたものの，主対象種であるマダコでは ほぼ同等の漁獲性能を持つ可能性が示された。また, いも焼酎かす餌料の海水中での減少量は, 寒天粉末量 が $20 \mathrm{~g}$ のときマサバよりも多かったが, 寒天粉末 量が25～ $50 \mathrm{~g}$ ではマサバに比べて少なかったことか ら, 寒天粉末量を $25 \mathrm{~g}$ 以上にすることで, 従来のマ サバよりも海洋の水質環境にやさしい慨料として利用 できる可能性が考えられた。

\section{4. コンクリート魚礁でのいも焼酎かすの活用}

日本沿岸には魚類の生息場を造成するために, コン クリートや鋼製の人工魚礁が設置されている。アミノ 酸は魚類を誘引するための有効な物質であり, 動植物 の成長に欠かせないものであるため, 海中に設置され るコンクリート構造物にアミノ酸を混ぜることによっ て, 従来よりも集魚効果や付着生物の成長を向上させ ることが期待できると考えた。焼酎の製造が盛んな鹿 児島では，アミノ酸を含んだいも焼酎かすが容易に， 多量に，そして安価に入手できるため，これは新しい 素材として活用できると考えたことも研究を行うこと になった動機のひとつである。

焼酎かすコンクリートの研究開発は平成 16 年に, 当時, 鹿児島県農業大学校で勤務されていた川井田博 氏と着手し, 翌年の平成 17 年には鹿児島共和コンク リート工業株式会社（鹿児島市）と共同で進めること
になった。コンクリートを製造するときに水の代わり に焼酎かすを用いると強度が弱くなり, 焼酎かすを 100\%にした場合では, 普通コンクリートの強度と比 べて約 10 分の 1 以下までに低下する。海中に設置す る構造物として十分な強度を持たせるための検討を重 ねていた頃, 有機物を固化させる技術を有する八光工 業株式会社（鹿児島市）にも共同開発に参画してもら うことができ，現在では十分な強度を持つコンクリー 卜に改善することができている。焼酎かすコンクリー 卜を開発に取り組んでいた頃は, 焼酎かすの海洋投棄 が全面禁止になる時期と重なったため, 焼酎かすをコ ンクリートに混ぜて海中に設置しょうという試みは, 形を変えた海洋投棄と捉えられることも少なくはなか つた。本研究の取り組みは焼酎かすの処理が目的では なく，前述したように海中に生息する生物にとって有 効な成分であるアミノ酸を含有させた人工魚礁をつく りたいというのが開発のコンセプトである。焼酎かす コンクリートの実施試験を開始する前に, 海洋環境に 対して悪影響がないかを明らかにするために, 海洋污 染防止法で定められている溶出試験を実施して, すべ ての項目で問題がないことを確認した上で, さらに実 験室の水槽で焼酎かすコンクリートを海水に浸漬させ て、コンクリート表面に着生する微生物について調べ た（写真 5)。海水中にコンクリートを設置すると, コンクリート表面にパイオニア細菌が付着し, さらに その上に多様な微生物 (細菌, 付着珪藻類, 原生生 物）が 2 次的に付着してバイオフィルムと呼ばれる薄 い膜が形成される（第 2 図）。このバイオフィルムの 中には, 周囲の環境と比較して高い密度で微生物が生 息する。バイオフィルムが形成される過程において,
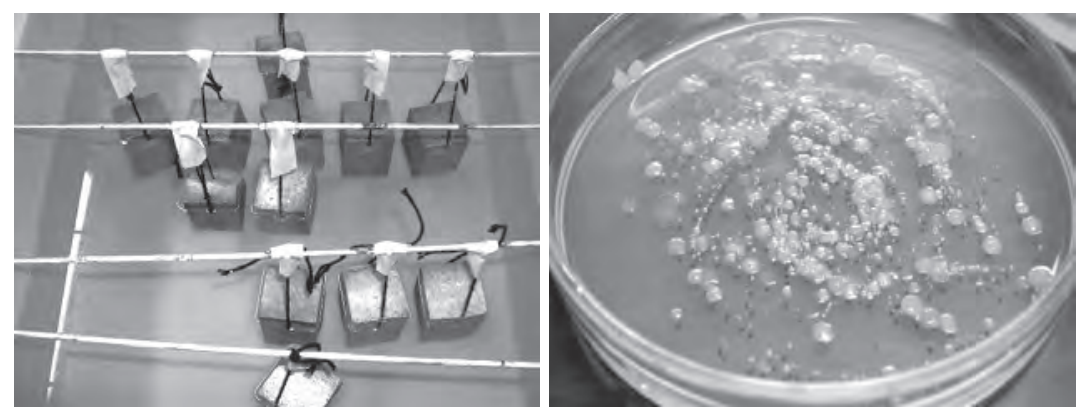

写真 5 海水に浸漬させた焼酎かすコンクリート(左) 表面に着生した微生物を培養(右) 


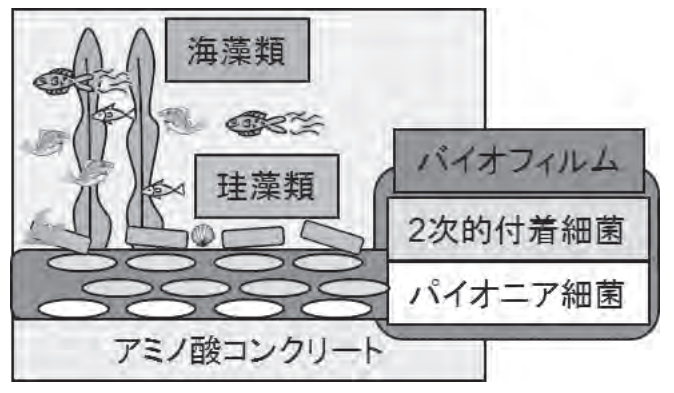

第 2 図 アミノ酸コンクリートによる効果

微生物が剥離したり, 再度付着したりして, 共生・拮 抗関係を経ながら微生物群集が安定化していく。焼酎 かすコンクリートでは，いも焼酎かすの中に含まれる アミノ酸などの有用成分が直接，バイオフィルム中の 微生物に対して栄養源を供給し, 微生物の働きを活性 化させるため, 水中の污染物質を分解する能力が高ま るのではないかと考えた。

\section{5.「いも焼酎かすコンクリート」から「アミノ酸 コンクリート」ヘ}

前述したように焼酎かすコンクリートに関する研究 開発を進めてきたが，さらに効果を高めるためにはア ミノ酸の濃度を高める必要がある。現在, 焼酎かすか らアミノ酸溶液を生成し，農作物の液肥としての販売 を行っている株式会社オパールと共同で開発を進めて おり，焼酎かすをそのままコンクリートに配合するの ではなく, 焼酎かすから生成されたアミノ酸濃縮液を コンクリートに配合するようにしている。

いも焼酎かすは酸性で腐敗しやすいため, 気温の高 いところで保管するとその性状が変化して異臭を発す ることがあり，また，出来上がったいも焼酎かすコン クリートの強度が不安定になることがある。また，い も焼酎かすを入手できる期間がいも焼酎の製造時期で ある秋から冬に限られるため，いも焼酎かすの少ない 春から夏にかけてはいも焼酎かすコンクリートの製造 ができないという問題も挙げられる。一方，いも焼酎 かすから生成したアミノ酸濃縮液は化学的に安定して おり常温で保管が可能で，周年を通じて利用すること ができるため取り扱いが非常に容易になる。

アミノ酸コンクリートの水質浄化作用を調べるため に次のような室内実験を行った。海水を入れた水槽を 6 つ用意して，その中で海産メダカであるジャワメダ

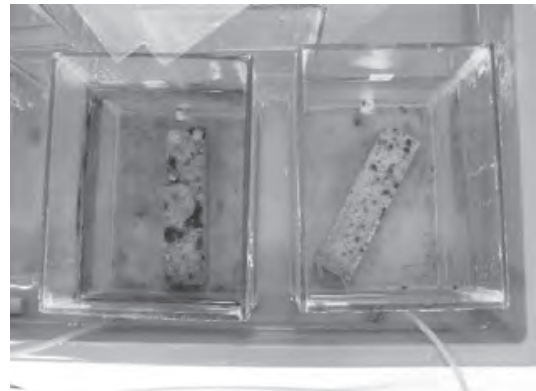

写真 6 ジャワメダカを飼育した水槽内に設置したア ミノ酸コンクリート (左) と普通コンクリート (右)

カを飼育した。6つの水槽のうち，アミノ酸コンクリ 一ト，普通コンクリートを入れた水槽を 2 つずつとし て, 残りの 2 つ水槽にはコンクリートを入れないコ ントロールとした。海水中のアンモニア濃度は時間が 経過するとともにジャワメダカの排泄物によって高く なるが、コンクリート表面に付着した微生物の働きに よって，アンモニアが亜硝酸，硝酸へと分解され無毒 化される。水槽内に設置したコンクリートの表面には バクテリアなどが付着して表面の色が変化しているの が目視でも観察された（写真 6)。実験の結果, 従来 のコンクリートと比べて, アミノ酸コンクリートの方 が速く海水中のアンモニア濃度が減少し, さらに無毒 化された硝酸の濃度が増加しているのが確認された (第 3 図)。

研究開発を開始した当初は焼酎かすコンクリートで あったが，現在ではアミノ酸コンクリートに生まれ変 わり, 鹿児島県内をはじめ北海道, 長崎県など 70 ケ 所以上で施工されている。代表的な例をいくつか紹介 したい。

種子島においてトコブシは重要な水産物のひとつで あり，地元では「ながらめ」と呼ばれ，刺身やみそ焼 きなどで食べられている。しかしながら, 現在では資 源の状態が悪化しているため, 最盛期であった頃から 比べて水揚げ量が 1 割程度まで減少している。資源を 回復させるために稚貝の放流が行われているが, 必ず しも水揚量の増加にはつながっていない。そこで写真 7 に示すように, トコブシが生息できなくなった砂地 の海底に魚礁を設置して, 生息場の環境を回復させる 試みを行っている ${ }^{13)}$ 。

鹿児島湾ではマダコの産卵場所を造成する産卵礁で 


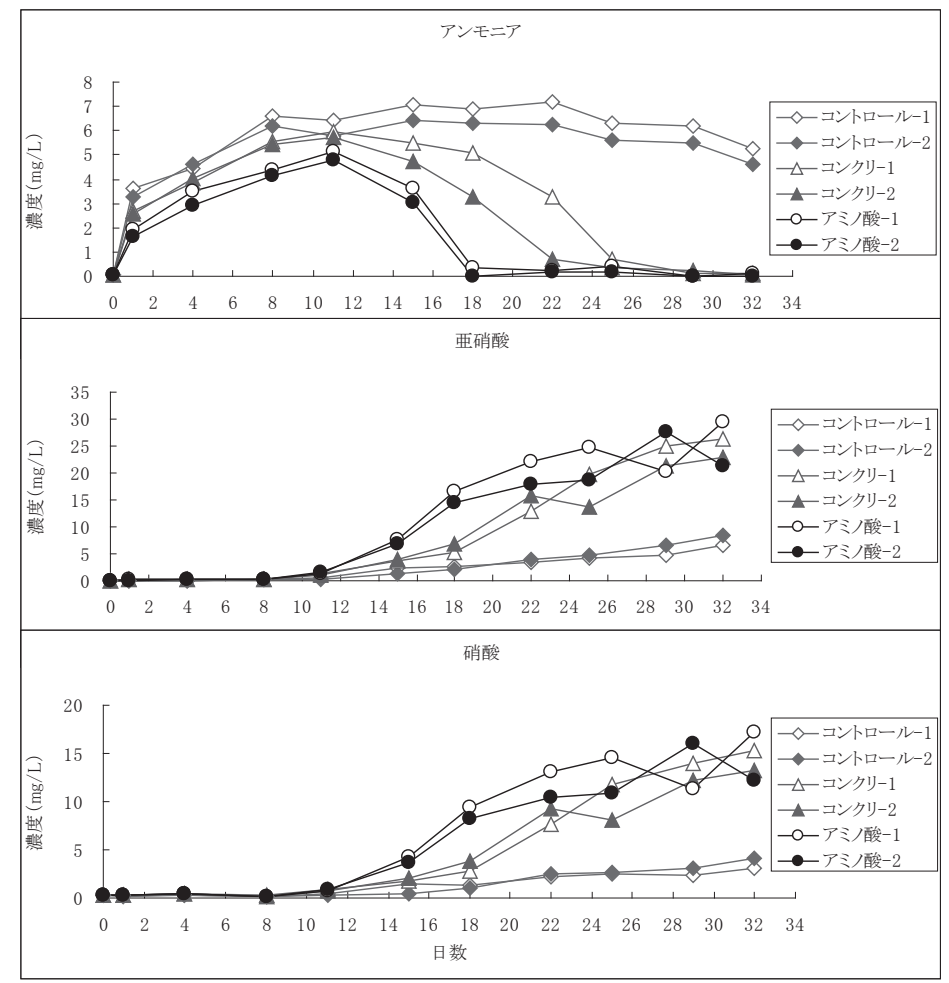

第 3 図 海水中のアンモニア(上), 覀硝酸(中), 硝酸(下)濃度の変化
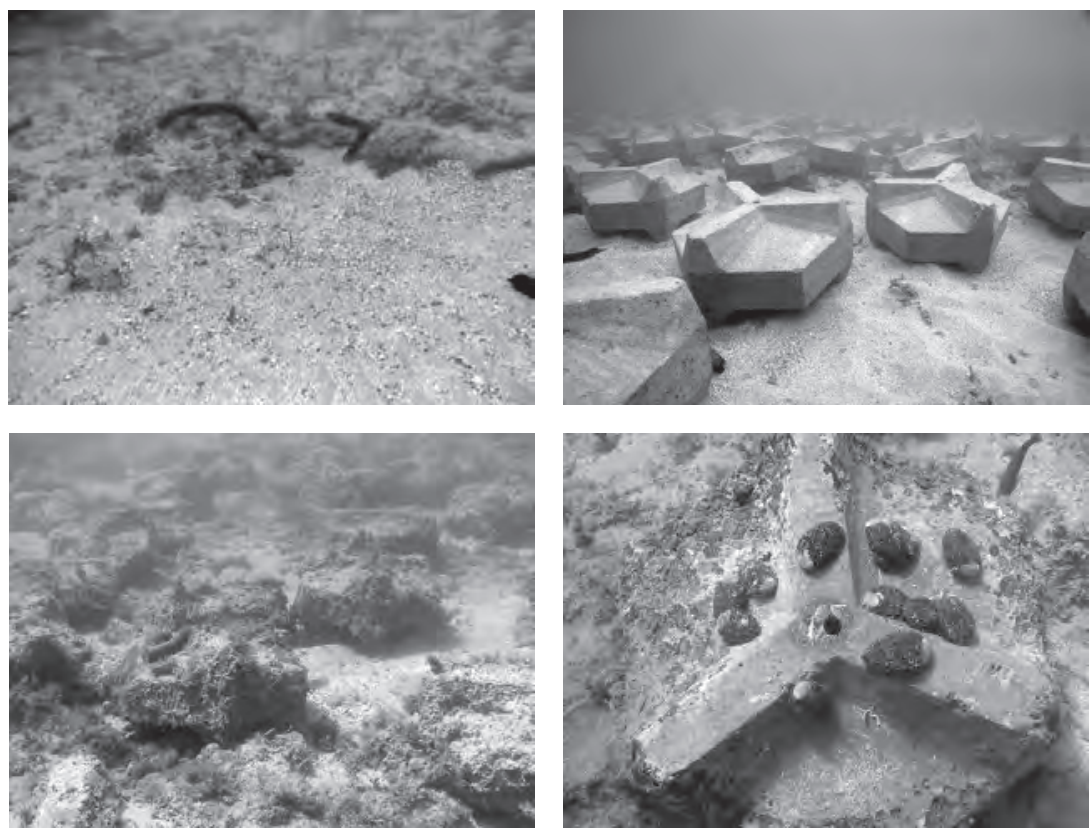

写真 7 トコブシ魚礁(種子島)

（左上：砂で埋もれトコブシが生息できなくなった海底，右上：トコブシ魚礁を設置，左下：設置 5 ケ月後には 海藻類が繁茂。右下：魚礁の裏面にトコブシが着生） 
アミノ酸コンクリートを活用している。鹿児島湾では 6 月頃から扮に盆にかてマダコ漁業の最盛期を迎え, その後はマダコの産卵期に入るため産卵礁を設置して, 禁漁期とするところが多い。写真 8 は, アミノ酸コン クリートで製作したタコつぼの中で，マダコが産卵し た様子を撮影したものである。

トコブシ魚礁やマダコ産卵礁の他には, 藻場を造成 するためのブロックや消波ブロック, 港湾の護岸ブロ ックなどに利用されている（写真 9, 10）。また, 内 水面では，ホ夕ルの生息場を造成するためにホ夕ルの 餌となるカワニナの着生が良くなるようにアミノ酸コ

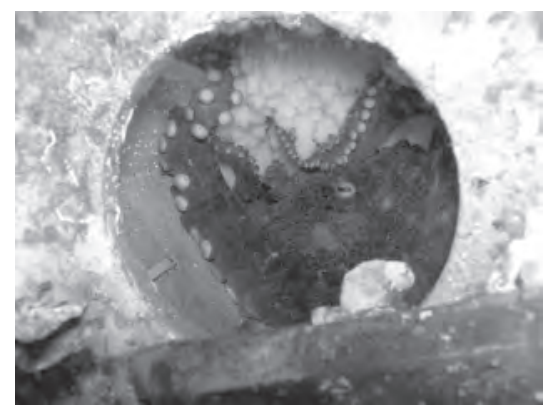

写真 8 産卵礁の中で産卵したマダコ(鹿児島湾)
ンクリートで溝を製作したり（写真 11）, 河川の護岸 ブロックなどでも採用されている。(写真 12)

\section{6. 今後の展開}

焼酎かすコンクリートおよびアミノ酸コンクリート による効果は, 設置した海域の水質, 水温, 照度, 流 速などの様々な影響を受けるため, 従来のコンクリー 卜とほほ同等な性能しか発揮されない場合もある。大 型のコンクリート構造物でアミノ酸コンクリートを利 用しょうとすると, 従来のコンクリートと比べて製造 コストがかかるため, その分, 製品価格も高くなる。 アミノ酸による効果は海水とコンクリートが接する構 造物の表面でのみ機能するため, 最近では小型平板で の利用を提案することが多くなってきている。写真 13 に示す小型平板は縦 $20 \mathrm{~cm} \times$ 横 $20 \mathrm{~cm} \times$ 厚さ 3 $\mathrm{cm}$ で質量が約 $3 \mathrm{~kg}$ で軽量であるため, 大型の構造 物の表面に貼り付けて利用することでコスト面での負 担を軽減することができ, 予算規模に応じて必要な分 だけを導入することができる。また，長期間の使用に よって,アミノ酸の効果が低下してきた時には新しい ものに交換をすることもできる。
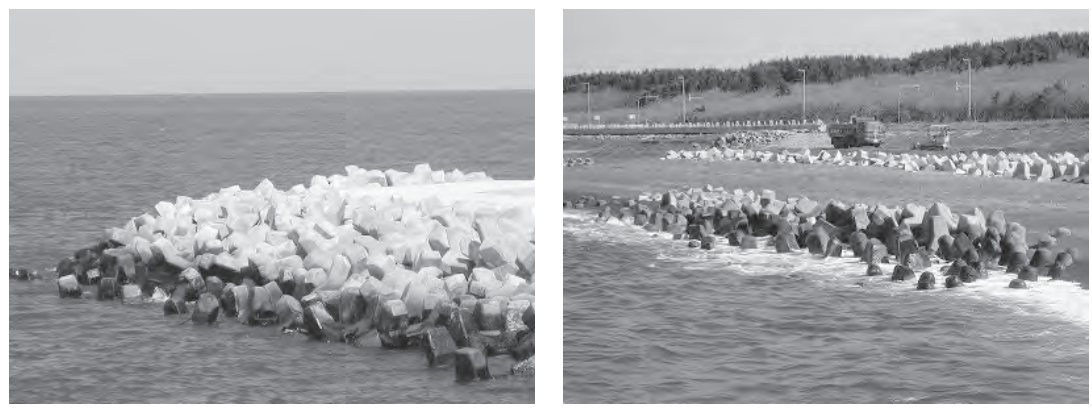

写真 9 消波ブロック (北海道紋別郡興部町)
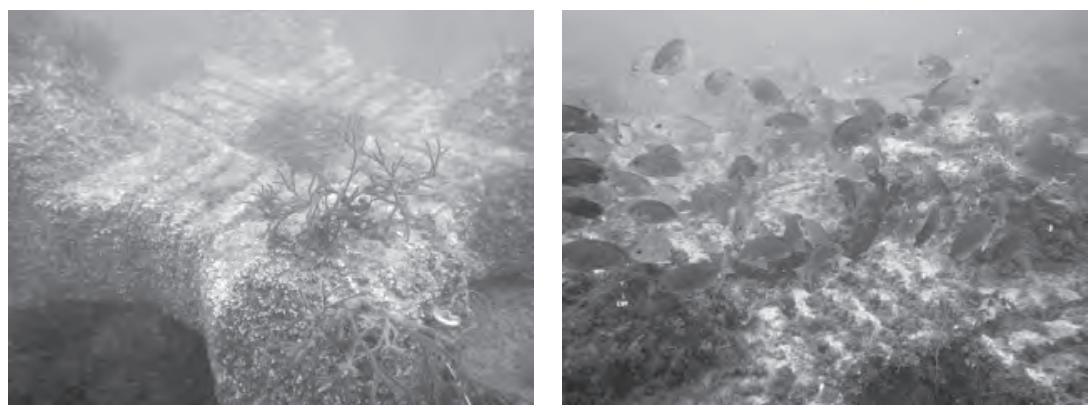

写真 10 港湾の護岸ブロック(長崎県諫早市) 

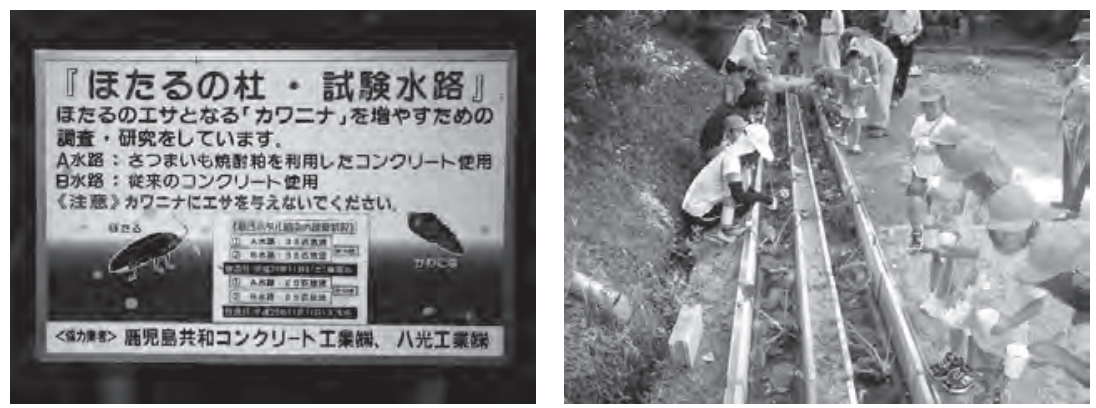

写真 11 ホ夕ル生息場造成(鹿児島県霧島市)
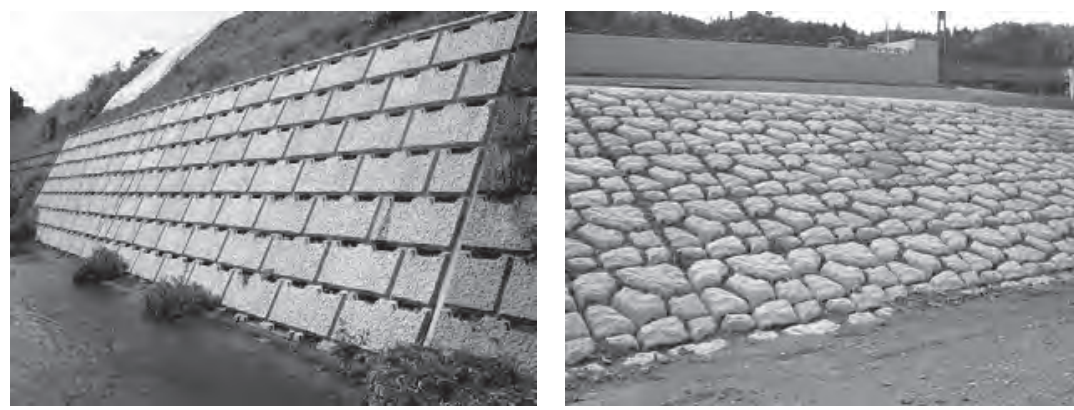

写真 12 河川防災工事 (左：鹿児島県曽於市財部町，右：鹿児島県伊佐郡湧水町)
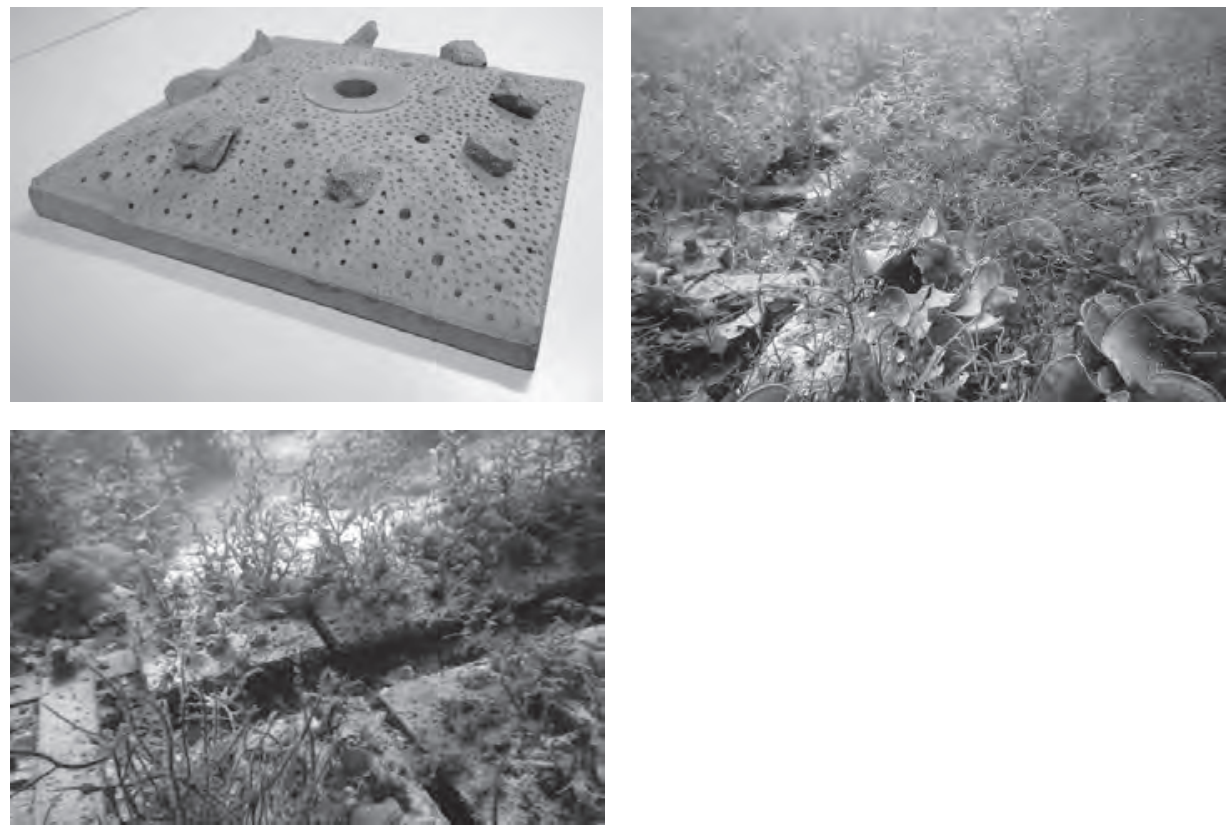

写真 13 アミノ酸コンクリートで製作した小型平板 (上右：鹿児島県志布志市, 下左：鹿児島県いちき串木野市) 
一昨年度からは新しい取り組みとして, 鹿児島工業 高等専門学校と共同して, アミノ酸コンクリートに不 足していた機能を補うための研究に着手している。海 水中の生物にとってアミノ酸と同様に重要であるミネ ラル成分を，焼酎かすと同じく産業廃棄物であるきの こ廃培地と混ぜ合わせることで，また，吸着性の高い 浄化作用を持つ孟宗竹も混合させて, さらに効果の高 い製品にすることを試みている。鹿児島県にある未利 用資源である焼酎かす，きのこ廃培地，孟宗竹の有効 活用を図ると同時に，機能性の高いコンクリート製品 を開発できるように今後も研究を重ねていきたいと考 えている。

\section{〈鹿児島大学水産学部 准教授}

\section{参考文献}

1）板沢靖男 - 羽生功 編: 魚類生理学, 恒星社厚 生閣 (1991).

2）会田勝美·金子豊二 編 : 魚類生理学の基礎, 恒星社厚生閣（2013）.

3）原田勝彦 編：魚介類の摂餌刺激物質, 恒星社 厚生閣（1994）。

4）科学技術庁研究調整局，アルコール発酵母液の 再資源化に関する総合研究 - 稚仔魚生産用初期 生物餌料の大量生産への応用 - (1982).

5）今田克・斎藤祐一：ノリ葉体の生長に及ぼすア ミノ酸等の効果－Ｉ．アミノ酸のとりこみと生 長促進効果, 日本水産学会誌, 37, 1125-1133
(1971).

6）今田克・斎藤祐一：ノリ葉体の生長に及ぼすア ミノ酸等の効果 - II, 日本水産学会誌, 37, 1134-1139 (1971).

7）山内正仁 · 平田登基男 · 松藤康司 · 増田純雄 前野祐二・三原めぐみ・米山兼二郎：甘藷㧍よ び麦焼酎蒸留かすで作られた蘇生紙の物理・力 学的特性の廃液性状の比較検討. 廃棄物学会論 文誌 10，284-292（1999）

8）再生する焼酎かす～陸・人・海への有効活用〜, 鹿児島大学水産学部紀要, 特別号 (2007).

9）江幡恵吾 - 竹本牧・安樂和彦 : 焼酎蒸留かすに 対するトコブシ Haliotis diversicolor の摂餌特 性, 日本味と匂学会誌, 17 (3), 495-498（2010）。

10) Nakamura K, Archdale M. V.: Activity patterns of abalone under experimental conditions. Aquaculture Research 32, 169-179 (2001)

11）西村和久・伊藤茂：フクトコブシの摂飭につい て. 水産増殖 17, 27-32（1969）

12）江幡恵吾 · 安樂和彦 ·横田和晃 - 久木山友一 : 甘藷焼酎蒸留かすを固化したかご漁具用餌料の マダコに対する誘引効果, 日本味と匂学会誌, 16 (3), 589-592 (2009).

13）江幡恵吾 - 東輝 · 塩満曉洋 · 税所誠一 - 井手陽 一・砂坂育男：種子島沿岸に扮ける小型魚礁ブ ロックを用いたトコブシ生息場の環境修復, 海 洋開発論文集，25，129-134（2009）。
執筆者紹介（順不同・敬称略）

江幡恵吾 $<$ Keigo EBATA $>$

昭和 48 年 3 月 1 日生まれ 勤務先と所在地 $>$ 鹿児島

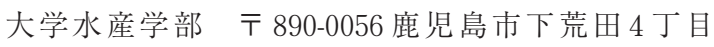
$50-20<$ 略歴 $>$ 平成 8 年 3 月北海道大学水産学部漁業 学科卒業, 平成 10 年 3 月北海道大学大学院水産学研 究科漁業学専攻修了, 平成 10 年 4 月～平成 11 年 11
月北海道漁業協同組合連合会, 平成 11 年 12 月鹿児島 大学水産学部助手, 平成 19 年 4 月鹿児島大学水産学 部助教, 平成 22 年 7 月鹿児島大学水産学部准教授 <抱負＞扔いしい魚を漁獲する方法について日々研究 していますので, これをさらに追求していきたいと考 えています。く趣味〉おいしいお酒と看を楽しむこと 